\title{
Assessing knowledge of social representations of climate change and tourism
}

\author{
M. B. Gómez-Martín \& X. A. Armesto-López \\ Department of Physical Geography and Regional Geographical Analysis, \\ University of Barcelona, Spain
}

\begin{abstract}
The aim of this study was to explore how university students of Spain perceive climate change and its effects on and relationship to the Spanish tourism sector, and their attitudes towards this issue. This included the identification of the problem, the relative importance it was given compared to other problems, assessment of the potential threat it posed to the tourism sector and appraisal of the contribution made by the tourism sector to climate change. The methodology employed was a survey: 400 individual questionnaires were administered to university students. The exploitation of the information collected is performed by using univariate descriptive procedures. The results indicate a low level of awareness among this young segment of population of the risks associated with climate change, which is seen as representing little threat to the tourism sector and as being distant in time and space. Through our study, we aimed to contribute to filling the void which currently exists as regards to understanding how different segments of population construct their representations of the inter-relationship between climate change and tourism, since such knowledge could help improve the effectiveness of the adaptation and mitigation strategies which are being, or could be designed and implemented in both the public and private tourism sectors.
\end{abstract}

Keywords: tourism, perceptions, attitudes, climate change, adaptation, Spain.

\section{Introduction}

The evidence of sustained global warming of the Earth's surface throughout the last century has established climate change as one of the main subjects of debate and concern in the context of current global economic policies which will dictate the future of the planet in coming years $[1,2]$. 
The importance of tourism in the world economy, and the undeniable links which exist between tourism and atmospheric elements, suggest that climate change should be considered in all its aspects [3]. Accordingly, it is worth noting that weather and climate are important elements of many of the tourism products offered by tourist destinations and thus, any change in atmospheric conditions could have a considerable impact [4-9]. Similarly, it should not be forgotten that tourism has been, and is, one of the factors responsible for climate change: at present, tourism reflects the general energy consumption model of the industrial revolution, generating high carbon emissions. Indeed, on a global scale the tourism sector is responsible for 5\% of greenhouse gas emissions [10-12]. Consequently, and given the importance of tourism to the economies of many countries worldwide, research into potential adaptation and mitigation measures in relation to climate change, are of prime interest [13-15].

For all strategies designed as a response to climate change, whether adaptation proposals or mitigation measures, consideration of the social factor is fundamental if an effective response is to be designed and implemented in order to avert the most pessimistic future scenarios [16]. Through our study, therefore, we aimed to contribute to enhancing knowledge of how citizens construct their representations of the inter-relationship between climate change and tourism, since such knowledge could help improve the effectiveness of the adaptation and mitigation strategies which are being, or could be, designed and implemented in the both public and private tourism sectors.

Few studies have examined the social representations of the inter-relationship between climate change and tourism. In other words, little research has been conducted into how citizens perceive this phenomenon, how it is identified, what beliefs and knowledge they hold about it, what importance they grant it compared to other decisions which may affect their purchase decisions, what their assessment is of the potential threat climate change poses for the tourism sector, what perceptions they have of their individual or collective responsibility for this phenomenon, etc. Becken [17] has highlighted the need for such studies, due to the significant contribution they could make in the preparation of effective communication campaigns for raising awareness among tourists of the importance of climate change and motivating them to take action.

Much of the research which has been carried out in this field has focused on exploring the importance of atmospheric variables when selecting destinations, with the aim of enabling assessment, a posteriori, of the impacts that future changes in these variables could have on tourism consumers' decisions and, consequently, on tourist flows. Thus, for example, Braun et al. [18] conducted a study to ascertain the socio-economical impacts on the tourism sector of climate change, assessing how tourists would behave under different future scenarios as regards selection of their destination. The study, which focused on the north coast in Germany, indicated that the phenomenon could have a significant influence on this process, potentially leading to a future change in the influx of tourists to this region. Also studies by Amelung and Viner [19], Amelung et al. [20], Bigano et al. [21], Hamilton et al. [22], Lise and Tol [23], Maddison [24] and Scott et al. [25] examine the changes that climate change could have on the 
current weather conditions for some destinations, and how those changes may impact on future tourism demand flows. To our study area, the results of these studies predict in most cases quite pessimistic future. These contributions, made with a quantitative approach (based mainly on the use of econometric techniques), rarely incorporate the social dimension and, therefore, these contributions do not consider some aspects that can influence the future tourist behavior and which have to do with perceptions, opinions and attitudes towards the phenomenon. Maybe working scales used and macromagnitudes considered in some of these works have hampered the introduction of this variable more "humane".

Qualitative approaches allow the introduction of the social dimension, however, these studies are fewer than quantitative approaches. Focusing on Zanzibar, Tanzania, Gössling et al. [26] studied tourist perceptions of climate change and the importance of climate in tourist decisions. Among other conclusions, the authors indicated that some of the changes associated with climate change (such as higher temperatures) were not perceived by tourists to be a significant problem, whereas others, such as increased rainfall and humidity, were, and that these latter could have a negative influence on choice of destination. The authors also explored the degree of awareness among tourists of how their tourism behaviour influenced, or could influence climate change, and found that tourists within the study area showed little awareness and assumed little responsibility. Similarly, Becken [27] took New Zealand as the study area and explored tourists' knowledge and awareness of the contribution made by air transport to climate change, their sense of individual responsibility and their reactions to specific climate change mitigation policies. The results indicate scant willingness on the part of tourists globally to change their tourism consumer habits, particularly with respect to transport, and revealed a disparity among those interviewed between their behaviour as tourists and their everyday behaviour (much more proactive and self-effective). Other studies, such as those by Dawson et al. [28] on long-distance tourists travelling to Canada to watch polar bears, or by Cohen and Higham [29] on tourists from the United Kingdom travelling to New Zealand, obtained similar results.

McKercher et al. [30] demonstrated the significant disparity between awareness and action, identifying different tourist profiles according to these variables and calling for governmental intervention to bring about a change in environmental attitudes among tourists. In an exploratory study, Becken [31] analysed how tourists and tourism experts perceived climate change and the carbon sinks provided by forests as a tool for offsetting carbon dioxide emissions. As regards tourists, the study identified five groups, each of which would require a different approach in order to ensure effectiveness of the educational campaigns which the sector could implement to address this phenomenon through adaptation or mitigation.

Marshall et al. [32] and Scott et al. [33] assessed awareness of and attitudes to climate change among tourists who had chosen diving in the Red Sea (Egypt). In this case, the study found a disparity in the results depending on whether those interviewed were the tourists (who reported high awareness and proactive 
attitudes), or the destination operators (who reported that their clients demonstrated moderate awareness and little evidence of proactive attitudes). This disparate perception hinders development and implementation by the sector of measures which could contribute to adaptation to, or mitigation of, climate change.

In this paper, we present the results obtained from a survey aimed at exploring how university students of Spain perceive climate change in relation to tourism, and their attitudes to it. Understanding how different segments of population construct their social representations of climate change and its consequences and risks for the Spanish tourism sector, and how such representations condition their attitudes and tourist behaviour, is a fundamental step in designing the education and communication campaigns necessary to ensure the success of the adaptation or mitigation measures which could be implemented by this sector. Consideration of these aspects could have a great significance for a country where tourism brings to the Spanish economy around $11 \%$ of GDP.

\section{Method and data collection}

The results of the present study are based on 400 questionnaires which were administered between 2008 and 2009. The reporting unit to which the study addressed was university students of Spain of both sexes over 18 years old. This is a segment of young population in educational / work transit that can provide valuable information for future action on climate change. The data collection method used was the classic collection called PAPI (Paper Assisted Personal Interviewing) that is personal surveys that are conducted by a pollster who uses the paper support.

The questionnaire was semi-structured (with open and closed questions) and it sought to explore how university students of Spain perceive the binomial climate-tourism. This included identification of the problem, the relative importance it was given compared to other problems, assessment of the potential threat it posed to the tourism sector and appraisal of the contribution made by the tourism sector to climate change. The exploitation of the information collected is performed by using univariate descriptive procedures.

$41 \%$ of the college students interviewed were male, and $59 \%$ female; $43 \%$ were between 18 and 20 years old, $47 \%$ between 20 and 25 and only $10 \%$ were aged over 25 years old. As other authors, working with similar segments [33], have warned, one possible limitation of the study could be the homogeneity of the demographic, cultural and social variables presented by the section of the population analysed: the results are representative of young adult university students. Nevertheless, it is of particular interest to explore the public perceptions and attitudes regarding the effects of climate change on the tourism sector held by this section of the population which by 2025 and 2050, dates by which most of the climate scenarios will have become reality, will have attained maximum mobility. 


\section{Results}

\subsection{Identification of climate change as a problem}

Subjects were asked about the future problems that concerned them, whether generic or specific (in this case, focusing on environmental issues and in climate change), and offered specific response options.

Thus, the sample was asked about their concern with a battery of basic questions. For the respondents, environmental issues occupied the first place in their scale of future concerns compared to other social or economic issues closely related to the everyday life of the section of the population surveyed. Thus, the environment scored 4.2 on a Likert scale of 1 to 5 , followed by problems related to human rights (4.14), terrorism and citizen safety (3.61), the economy (3.51), technological development (3.21) and immigration (2.96) (Table 1). These results suggest that there is public awareness of environmental issues among this market's sector, in agreement with the cultural tendencies of industrialised societies. Nevertheless, the priority given to these issues over other problems which could have more relevance in the immediate future life of those surveyed is somewhat surprising: it may be relevant here to consider the possibility of social desirability bias, so frequent in studies of values, attitudes and perceptions regarding the environment [34-36].

Table 1: $\quad$ Thinking about your immediate geographical surroundings in the future, to what extent are you concerned about the following problems?

\begin{tabular}{|c|c|c|c|c|c|c|c|c|}
\hline & $\begin{array}{c}\text { Weighted } \\
\text { mean }\end{array}$ & Median & $\begin{array}{c}1 \\
\text { Not } \\
\text { worried }\end{array}$ & 2 & 3 & 4 & $\begin{array}{c}5 \\
\text { Very } \\
\text { worried }\end{array}$ & $\begin{array}{c}\text { No } \\
\text { opinion }\end{array}$ \\
\hline $\begin{array}{c}\text { Terrorism and } \\
\text { citizen safety }\end{array}$ & 3.61 & 4 & $5.70 \%$ & $14.25 \%$ & $19.37 \%$ & $34.47 \%$ & $25.93 \%$ & $0.28 \%$ \\
\hline Inmigration & 2.96 & 3 & $15.95 \%$ & $21.94 \%$ & $24.22 \%$ & $25.36 \%$ & $12.25 \%$ & $0.28 \%$ \\
\hline Environment & 4.26 & 4 & $0.85 \%$ & $3.99 \%$ & $11.11 \%$ & $36.47 \%$ & $47.29 \%$ & $0.28 \%$ \\
\hline Human rights & 4.14 & 4 & $1.14 \%$ & $2.28 \%$ & $18.52 \%$ & $37.32 \%$ & $40.46 \%$ & $0.28 \%$ \\
\hline $\begin{array}{c}\text { Technological } \\
\text { development }\end{array}$ & 3.21 & 3 & $8.55 \%$ & $16.81 \%$ & $30.77 \%$ & $32.19 \%$ & $11.40 \%$ & $0.28 \%$ \\
\hline Economy & 3.51 & 4 & $5.13 \%$ & $9.97 \%$ & $31.34 \%$ & $35.04 \%$ & $18.23 \%$ & $0.28 \%$ \\
\hline
\end{tabular}

When the sample is asked about his opinion regarding a battery of environmental problems, the issue of climate change is the aspect that received lower scores in the geographical area of study (albeit with minor differences compared to other items), compared with a wide range of other environmental problems. Thus, soil and water pollution obtained a mean score of 4.5 on a scale of 1 to 5, followed by the destruction and loss of species (4.37), atmospheric pollution (4.30), fires (4.29), exhaustion of energy resources (4.25) and, in last 
place, climate change (4.23). Note that all scores are high relative to the offered Likert scale (1 Not at all worried -5 Very worried), including climate change score. However, in items like climate change and exhaustion of energy resources, the percentage of respondents who indicated a value of 1 and/or 2 of the scale is somewhat higher in relation to other items (Table 2). These results could show that on a regional or local level, climate change is perceived as a minor problem compared with other environmental issues. Various studies not specific to the tourism sector carried out in the last decade have reported the same tendency [37]: the phenomenon of climate change is perceived as relevant on a global scale, but loses precedence over other environmental issues as the perspective is reduced to a regional, and then local scale. This may possibly be due to the fact that our senses have great difficulty in detecting evidence of climate change in the present, to the widespread publicity given to reports on climate change or tourism published by different international organisations [38-42], where the results are systematically presented on both a global and specific macroregional scale for the medium and long term, to the scant publicity afforded to regional and local reports, and to insufficient efforts as regards providing information linking climate change with the everyday lives of tourists.

Table 2: $\quad$ Thinking about your immediate geographical surroundings in the future, to what extent are you concerned about the following environmental problems?

\begin{tabular}{|c|c|c|c|c|c|c|c|c|}
\hline & $\begin{array}{c}\text { Weighted } \\
\text { mean }\end{array}$ & Median & $\begin{array}{c}1 \\
\text { Not } \\
\text { worried }\end{array}$ & 2 & 3 & 4 & $\begin{array}{c}5 \\
\text { Very } \\
\text { worried }\end{array}$ & $\begin{array}{c}\text { No } \\
\text { opinion }\end{array}$ \\
\hline Atmospheric pollution & 4.30 & 4 & $0.57 \%$ & $3.13 \%$ & $8.83 \%$ & $40.46 \%$ & $46.44 \%$ & $0.57 \%$ \\
\hline $\begin{array}{c}\text { Exhaustation of energy } \\
\text { resources }\end{array}$ & 4.25 & 5 & $1.14 \%$ & $5.13 \%$ & $13.96 \%$ & $26.78 \%$ & $52.71 \%$ & $0.28 \%$ \\
\hline Climate Change & 4.23 & 4 & $0.85 \%$ & $4.84 \%$ & $9.69 \%$ & $39.60 \%$ & $44.73 \%$ & $0.28 \%$ \\
\hline Fires & 4.29 & 4 & $0.00 \%$ & $3.42 \%$ & $12.82 \%$ & $35.33 \%$ & $48.15 \%$ & $0.28 \%$ \\
\hline $\begin{array}{c}\text { Destruction and loss of } \\
\text { species }\end{array}$ & 4.37 & 5 & $0.28 \%$ & $1.99 \%$ & $13.11 \%$ & $29.34 \%$ & $54.99 \%$ & $0.28 \%$ \\
\hline Soil and Water pollution & 4.50 & 5 & $0.28 \%$ & $1.42 \%$ & $7.41 \%$ & $29.63 \%$ & $60.68 \%$ & $0.57 \%$ \\
\hline
\end{tabular}

\subsection{Perceptions of climate change and tourism}

To investigate the level of awareness of climate change and tourism, two questions have been made. Thus, respondents were questioned about whether climate change will have an effect on tourism in the immediate geographical environment and how could be these effects on. In relation to the first question, only $86 \%$ answered in the affirmative, whilst $9 \%$ said no and $5 \%$ had no opinion. In response to how, those surveyed made particular mention of the negative effects on sun-and-beach tourism, highlighting the problems associated with pressure on water resources, loss of beaches and the degradation and diminishing attractions of tourism destinations due to loss of biodiversity. In no instance was an increase in temperatures and the effects of this on comfort levels mentioned as 
a serious problem by any of those surveyed. On the other hand, respondents repeatedly mentioned the consequences for Spanish tourism of other, competing destinations unaffected by the environmental impacts produced by climate change (Figure 1).

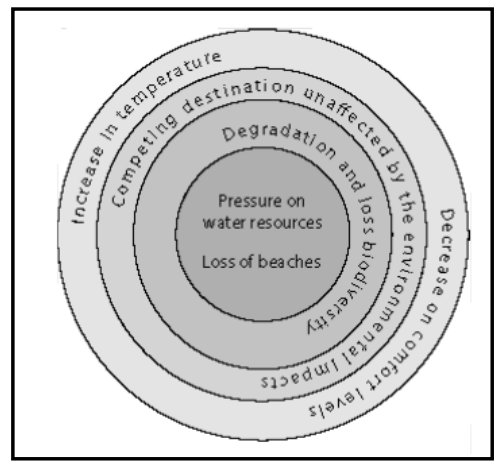

Figure 1: Perceived impacts of climate change on tourism.

Similarly, respondents were questioned about if tourism contributes in some way to climate change and how. In this case, $76 \%$ answered yes, $23 \%$, no, and $1 \%$ had no opinion. Related with how, respondents who had answered in the affirmative way, placed more emphasis on the effects of tourism on environmental aspects such as degradation of water, coastal areas, pressure on resources, etc., than on the effects of tourism on climate (those surveyed tended to identify many of the environmental impacts generated by tourism with climate change, when in fact they are not always related). Of the $76 \%$ indicated, few emphasised the consequences for the atmosphere of air transport or the increase in energy consumption associated with tourism, to cite some examples. It seems that respondents perceive more easily the impacts of climate change on tourism, and have a greater difficulty to perceive tourism impacts on climate change.

To complete these questions, subjects were asked which aspects in the study area would be most affected by climate change, and offered specific response options. This inquiry into the situation of the tourism sector in the context of climate change, contrasting it with other sectors of the economy or strategic issues within the field of study, obtained a highly surprising result: the tourism sector reaches a 3.5 on a Likert scale of 1 to 5 , the lowest score of the set (Table 3 ). Note for the tourism sector, the high percentage of answers that are at the value 1 and 2 .

Finally, it is also interesting to examine the results obtained when respondents were asked to assess the immediacy of the effects of climate change at a generic and a specific (the tourism sector) level (Table 4). There appears to be little real understanding of the consequences of climate change for the tourism sector among respondents: low perceptions of threat due to difficulties in recognising the effects of climate change on the tourism sector at present evidences once 
again the difficulties encountered in relating this phenomenon (in special, tourism/climate change) to our immediate everyday surroundings.

Table 3: Thinking about your immediate geographical surroundings in the future, to what extent do you think the following aspects could be affected by climate change?

\begin{tabular}{|c|c|c|c|c|c|c|c|c|}
\hline & $\begin{array}{c}\text { Weighted } \\
\text { mean }\end{array}$ & Median & $\begin{array}{c}1 \\
\text { Unaffected } \\
\end{array}$ & 2 & 3 & 4 & \begin{tabular}{|c|}
5 Very \\
affected \\
\end{tabular} & \begin{tabular}{|c|} 
No \\
opinion \\
\end{tabular} \\
\hline Energy sector & 3.60 & 4 & $2.28 \%$ & $11.11 \%$ & $28.77 \%$ & $37.89 \%$ & $18.52 \%$ & $1.42 \%$ \\
\hline Water resources & 4.34 & 5 & $0.28 \%$ & $3.70 \%$ & $8.26 \%$ & $36.47 \%$ & $50.43 \%$ & $0.85 \%$ \\
\hline Human health & 3.97 & 4 & $0.57 \%$ & $4.27 \%$ & $20.51 \%$ & $46.44 \%$ & $27.35 \%$ & $0.85 \%$ \\
\hline Tourism sector & 3.50 & 4 & $2.56 \%$ & $12.25 \%$ & $32.48 \%$ & $36.47 \%$ & $15.10 \%$ & $1.14 \%$ \\
\hline $\begin{array}{c}\text { Terrestrial } \\
\text { ecosystems }\end{array}$ & 4.19 & 4 & $0.57 \%$ & $3.42 \%$ & $14.25 \%$ & $39.32 \%$ & $41.60 \%$ & $0.85 \%$ \\
\hline $\begin{array}{l}\text { Continental and } \\
\text { marine aquatic } \\
\text { ecosystems }\end{array}$ & 4.20 & 4 & $2.28 \%$ & $3.42 \%$ & $13.68 \%$ & $33.05 \%$ & $46.72 \%$ & $0.85 \%$ \\
\hline Fishing sector & 3.89 & 4 & $2.56 \%$ & $5.13 \%$ & $22.22 \%$ & $39.89 \%$ & $29.06 \%$ & $1.14 \%$ \\
\hline $\begin{array}{c}\text { Plant and animal } \\
\text { biodiversity }\end{array}$ & 4.29 & 4 & $0.28 \%$ & $2.28 \%$ & $11.97 \%$ & $38.75 \%$ & $45.87 \%$ & $0.85 \%$ \\
\hline Agricultural sector & 4.19 & 4 & $0.85 \%$ & $1.42 \%$ & $16.81 \%$ & $39.03 \%$ & $41.03 \%$ & $0.85 \%$ \\
\hline Coastal areas & 4.06 & 4 & $2.56 \%$ & $4.56 \%$ & $15.10 \%$ & $39.32 \%$ & $37.61 \%$ & $0.85 \%$ \\
\hline
\end{tabular}

Table 4: When do you think the effects of climate change will begin to have an impact? When do you think the effects of climate change will begin to have an impact on the tourism sector?

\begin{tabular}{|c|c|c|}
\hline & Generic & Tourism sector \\
\hline It is causing impacts at the moment & $5.41 \%$ & $2.56 \%$ \\
\hline $\begin{array}{r}\text { It is causing impacts at the moment and will also cause them in the } \\
\text { future }\end{array}$ & $90.03 \%$ & $56.13 \%$ \\
\hline $\begin{array}{r}\text { It will only cause impacts in the future, in the short term }(10-20 \\
\text { years })\end{array}$ & $2.28 \%$ & $19.37 \%$ \\
\hline $\begin{array}{r}\text { It will only cause impacts in the future, in the long term }(20-50 \\
\text { years })\end{array}$ & $0.85 \%$ & $17.38 \%$ \\
\hline It will not cause any impacts & $0.57 \%$ & $3.13 \%$ \\
\hline No opinion & $0.85 \%$ & $1.42 \%$ \\
\hline
\end{tabular}

\subsection{Valuation of information provided on climate change and tourism}

Two questions have been raised regarding the level of information: 1) Do you believe the information provided by the media about climate change is adequate in quantity and quality? Why? and 2) Do you believe the information provided by the media about the impacts of climate change on the tourism sector is 
adequate in quantity and quality? Why? Those surveyed reported that the information they received on the general effects of climate change is insufficient in terms both of quality and quality, an inadequacy which intensified as regards specific information concerning the effects of climate change on the tourism sector (Table 5). Respondents did not give a positive assessment of information provided about the general or specific effects of climate change, and reported having received generalised information with a clearly catastrophic and alarmist bias, rendering it less credible or resulting in attitudes of stoicism.

Thus, as regards the level of basic information that this section of the population possessed about climate change in the study area, our findings indicate that their knowledge was quite biased. When asked about the nature of the possible impacts of climate change on the study area, a catastrophic vision predominated: $53 \%$ of those surveyed believed that the impacts would be very negative, and $34 \%$, negative. Only $2 \%$ felt that the effects might be positive, $0 \%$ very positive, and $9 \%$ thought that the effects would be neutral. $1 \%$ had no opinion.

Table 5: Information provided by the media on the general impacts of climate change, and impacts on the tourism sector in particular.

\begin{tabular}{|c|c|c|c|c|}
\hline & \multicolumn{2}{|c|}{ Climate Change } & \multicolumn{2}{c|}{ Climate Change and Tourism } \\
\hline & Quantity \% & Quality \% & Quantity \% & Quality \% \\
\hline 1 Inadequate & 21.94 & 27.92 & 29.06 & 31.34 \\
\hline 2 & 35.04 & 37.04 & 35.04 & 37.89 \\
\hline 3 & 21.94 & 22.51 & 23.36 & 25.07 \\
\hline 4 & 15.95 & 10.26 & 9.97 & 3.13 \\
\hline 5 Adequate & 3.99 & 1.42 & 0.85 & 0.85 \\
\hline No opinion & 1.14 & 0.85 & 1.71 & 1.71 \\
\hline
\end{tabular}

\subsection{Different modes of tourism and climate change}

When respondents were asked about the degree and nature of the effects of climate change on different modes of tourism, it became apparent that an implicit understanding existed of how these modes indicated varying degrees of awareness of or dependence on atmospheric elements and, consequently, how they would be affected in different ways: similarly, the responses once again showed low perception of the beneficial effects of some of the direct impacts of climate change (for example, increased duration of inter-seasonal periods, potentially leading to longer tourism seasons and reduced importance of the marked problem of seasonality, did not appear to be perceived by the respondents). Of all the modes of tourism, the one which was perceived to be most susceptible to being affected by climate change in our study area was snow tourism (4.10 on a scale of 1 to 5), followed by sun-and-beach (3.76) and nature tourism (3.56): those perceived to be least susceptible were nautical tourism (3.32), adventure sports tourism (3.14) and cultural tourism (2.39). The potential 
effects were perceived as positive as regards cultural tourism, negative for snow tourism and predominantly negative for nature and sun-and-beach tourism (Table 6). It should be noted that there were a high percentage of "no opinion" responses, perhaps reflecting the level of disinformation.

When asked who they thought was most aware of the impacts climate change could have on the tourism sector, respondents' answers clearly indicated the low level of concern among tourists as regards this issue. Tourists are not perceived to be the group which is most concerned about the consequences that climate change might have for the tourism sector: according to those surveyed, it is scientists and tour operators or agents in the sector who display higher levels of awareness (Table 7). Respondents indicate that tourists can modify their behaviour in response to climate change by choosing new destinations capable of satisfying their climatic preferences or by changing when they take their holidays, as long as these options do not involve significantly greater expense.

Table 6: Thinking about your immediate geographical surroundings in the future, to what extent do you think the following modes of tourism could be affected by climate change?

\begin{tabular}{|c|c|c|c|c|c|c|c|c|}
\hline & $\begin{array}{c}\text { Weighted } \\
\text { mean }\end{array}$ & Median & $\begin{array}{c}1 \text { Not at } \\
\text { all }\end{array}$ & 2 & 3 & 4 & $\begin{array}{c}5 \text { Very } \\
\text { much }\end{array}$ & $\begin{array}{c}\text { No } \\
\text { opinion }\end{array}$ \\
\hline Cultural tourism & 2.39 & 2 & $22.79 \%$ & $34.76 \%$ & $24.79 \%$ & $14.53 \%$ & $2.56 \%$ & $0.57 \%$ \\
\hline $\begin{array}{c}\text { Sun and beach } \\
\text { tourism }\end{array}$ & 3.76 & 4 & $7.12 \%$ & $11.40 \%$ & $15.38 \%$ & $29.63 \%$ & $35.90 \%$ & $0.57 \%$ \\
\hline Nautical tourism & 3.32 & 3 & $9.69 \%$ & $15.10 \%$ & $25.36 \%$ & $32.48 \%$ & $16.81 \%$ & $0.57 \%$ \\
\hline Snow tourism & 4.10 & 5 & $8.26 \%$ & $3.99 \%$ & $7.41 \%$ & $29.63 \%$ & $50.14 \%$ & $0.57 \%$ \\
\hline \begin{tabular}{c} 
Nature tourism \\
\hline $\begin{array}{c}\text { Adventure sports } \\
\text { tourism }\end{array}$
\end{tabular} & 3.56 & 4 & $3.42 \%$ & $11.40 \%$ & $28.21 \%$ & $39.32 \%$ & $17.09 \%$ & $0.57 \%$ \\
\hline
\end{tabular}

\begin{tabular}{|c|c|c|c|c|c|c|c|c|}
\hline & $\begin{array}{c}\text { Weighted } \\
\text { mean }\end{array}$ & Median & $\begin{array}{c}1 \\
\text { Negatively }\end{array}$ & 2 & 3 & 4 & $\begin{array}{c}5 \\
\text { Positively }\end{array}$ & $\begin{array}{c}\text { No } \\
\text { opinion }\end{array}$ \\
\hline Cultural tourism & 2.96 & 3 & $4.27 \%$ & $19.94 \%$ & $54.70 \%$ & $12.25 \%$ & $6.27 \%$ & $2.56 \%$ \\
\hline $\begin{array}{c}\text { Sun and beach } \\
\text { tourism }\end{array}$ & 2.27 & 2 & $33.05 \%$ & $27.35 \%$ & $19.66 \%$ & $12.25 \%$ & $5.13 \%$ & $2.56 \%$ \\
\hline Nautical tourism & 2.55 & 3 & $17.95 \%$ & $25.36 \%$ & $39.03 \%$ & $11.40 \%$ & $3.13 \%$ & $3.13 \%$ \\
\hline Snow tourism & 1.70 & 1 & $53.56 \%$ & $25.64 \%$ & $11.97 \%$ & $3.70 \%$ & $1.71 \%$ & $3.42 \%$ \\
\hline $\begin{array}{c}\text { Nature tourism } \\
\text { Adventure sports } \\
\text { tourism }\end{array}$ & 2.26 & 2 & $21.94 \%$ & $38.18 \%$ & $29.06 \%$ & $5.41 \%$ & $2.28 \%$ & $3.13 \%$ \\
\hline
\end{tabular}


Table 7: Who do you think is most aware of the impacts climate change could have on the tourism sector?

\begin{tabular}{|r|c|}
\hline & $\%$ \\
\hline Tourists & 9.11 \\
\hline Tour operators and the main agents involved in \\
the tourism sector & 27.78 \\
\hline Politicians & 7.33 \\
\hline Scientists & 37.11 \\
\hline None of the above & 6.22 \\
\hline All of the above & 6.22 \\
\hline Others & 6.22 \\
\hline No opinion & 0.00 \\
\hline
\end{tabular}

\section{Conclusions}

Respondents understanding of the risks associated with climate change suggest a low level of perception of the possible effects of this phenomenon on the tourism sector (Figure 2). Our findings indicate that the media and educational campaigns implemented in recent years regarding environmental issues have had a profound effect on young people: degradation of the environment appears to be their prime concern for the future. However, of the many environmental issues raised, climate change is not their main concern. Although they are conscious that the problem is already having an impact and that, above all, it will continue to do so in the future, climate change is perceived as an issue of great interest on a global scale, but not at local or regional levels. In other words, our findings indicate a low perception of the risks associated with climate change, which is perceived to be distant and unrelated to the everyday life of individuals. This perception is clearly related to the enormous difficulty our senses encounter in detecting the subtle manifestations of climate change in the present, and to the kind of information provided about this phenomenon. Thus, those surveyed did not give a positive assessment of the information provided as regards either general or specific effects of climate change, and reported having received generalised information of an evidently catastrophic and alarmist nature. Maybe that helps explain the low ability to perceive positive impacts of climate change on the tourism sector. The information provided by the media is fundamental for correct transmission of the evidence for global warming and associated impacts. The contents of such information contribute to creating public opinion, and should therefore be rigorous, responsible and associated with the everyday surroundings of the individual.

To a certain extent, the tourism sector is perceived as less susceptible to being affected by climate change than other sectors of the economy or strategic issues, and the effects were also perceived to be less apparent and immediate. This surprising situation may be related to the insufficient information provided by the media on the inter-relationship, mentioned earlier, between climate change and tourism: the rare headlines which appear tend to reflect generalised and sensationalist treatment of the issue, while the conditional and uncertain nature of long-term forecasts for the complex tourism system and the use of examples 
depicting distant geographical scenarios, all encourage the population to dismiss the problem and its consequences. Nevertheless, there are certain indications which suggest that this low perception is not merely the result of a lack of knowledge, or "ignorance": the vested interests evidenced by respondents in their possible role as tourism consumers condition their perceptions of the situation. They see what they want to see, enabling them to maintain and justify their own lifestyles and their personal, and often "unsustainable", forms of tourism consumption. This would explain why they do not see tourists as the group which is most concerned by climate change, but are aware of the concern of scientists, tour operators and agents in the tourism sector.

\begin{tabular}{|c|c|}
\hline Scale & $\begin{array}{l}\text { Climate change is a major problem in the global scale. } \\
\text { Climate change is a minor problem in the local scale. }\end{array}$ \\
\hline Vulnerability & $\begin{array}{l}\text { The tourism sector is not perceived as one of the most } \\
\text { vulnerable sectors to climate change. }\end{array}$ \\
\hline Direction & $\begin{array}{l}\text { The impacts of climate change on tourism are becoming } \\
\text { more visible than the impacts of tourism on climate change. }\end{array}$ \\
\hline Kinds of impacts & $\begin{array}{l}\text { The negative impacts of climate change on the tourism sector } \\
\text { are displayed more than the positive. } \\
\text { Indirect impacts of climate change on the tourism sector } \\
\text { are seen as more negative than the direct impacts. }\end{array}$ \\
\hline Timeframe & $\begin{array}{l}\text { The impacts of climate change on the tourism sector } \\
\text { are displayed in medium and long term. }\end{array}$ \\
\hline Actors & $\begin{array}{l}\text { Tourists are not perceived to be the group which is most concerned } \\
\text { about the consequences that climate change might have on tourism } \\
\text { sector. }\end{array}$ \\
\hline
\end{tabular}

Figure 2: Perceptions of climate change and tourism.

Low perception of the effects of climate change on the tourism sector, and of the tourism sector on climate change, may contribute to reduced awareness of personal and collective responsibility and, above all, demotivate present action, which is postponed until the future. For any climate change policy or strategy, whether adaptation or mitigation, consideration of the social factor will be fundamental in design and implementation of effective responses to avert the most pessimistic scenarios. It is therefore crucial for the tourism sector to provide truthful, close-to-home and scientifically correct information on the contribution of the tourism sector to climate change and vice versa. Crossdisciplinary educational and awareness raising campaigns on climate change are not sufficient: what is needed are specific campaigns that, led by the sector itself (from both the public and private sectors), will influence tourism consumers, rendering them aware and active. The great challenge: to increase environmental awareness among tourists and involve them in environmental action.

\section{Acknowledgement}

This study was conducted within the framework of a Plan Nacional de I+D+I research project sponsored by the Spanish Ministerio de Economía y Competitividad, reference number CSO2011-23404. 


\section{References}

[1] IPCC, Climate Change 2013: The Physical Science Basis. Contribution of Working Group I to the Fifth Assessment Report of the Intergovernmental Panel on Climate Change. Cambridge University Press: Cambridge, 2013.

[2] Stern, N., The Economics of Climate Change: The Stern Review. Cambridge University Press: Cambridge, 2006.

[3] Scott, D., Amelung, B., Becken, S., Ceron, P., Dubois, G., Gössling, S., Peeters, P. \& Simpson, M., Climate change and tourism. Responding to global challenges. United Nations World Tourism Organization: Madrid, 2008.

[4] Becken, S., The importance of climate and weather for tourism: literature review. Lincoln University, LEaP, Land Environment and People Miscellaneous Publications: Lincoln, 2010.

[5] Becken, S. \& Hay, J., Tourism and climate change - risks and opportunities. Channel View Pub: Cleveland, 2007.

[6] Gómez-Martín, M.B., Weather, climate and tourism. A geographical perspective. Annals of Tourism Research, 32(3), pp. 571-591, 2005.

[7] Hall, C.M., Tourism and Climate Change: Knowledge Gaps and Issues. Tourism Recreation Research, 33, pp. 339-350, 2008.

[8] Smith, K., The influence of weather and climate on recreation and tourism. Weather, 48, pp. 398-404, 1993.

[9] Wall, G. \& Badke, C., Tourism and Climate Change: an international perspective. Journal of Sustainable Tourism, 2(4), pp. 193-203, 1994.

[10] Scott, D., Amelung, B., Becken, S., Ceron, P., Dubois, G., Gössling, S., Peeters, P. \& Simpson, M., Climate change and tourism. Responding to global challenges. United Nations World Tourism Organization: Madrid, 2008.

[11] Lyle, C., Discussion Paper on Climate Change Mitigation Measures for International Air Transport. United Nations World Tourism Organization: Madrid, 2009.

[12] Peeters, P., Tourism and Climate Change Mitigation - Methods, Greenhouse Gas Reductions and Policies. NHTV Academics Studies, 6. NHTV. Breda University: Breda, 2007.

[13] Simpson, M.C., Gössling, S., Scott, D., Hall, C.M. \& Gladin, E., Climate Change Adaptation and Mitigation in the Tourism Sector: Frameworks, Tools and Practices. UNEP, University of Oxford, UNWTO, UNWMO: Paris, 2008.

[14] UNWTO, From Davos to Copenhagen and Beyond: Advancing Tourism's Response to Climate Change. UNWTO Background paper, UNWTO: Madrid, 2009.

[15] WTTC, Leading the Challenge on Climate Change. World Travel \& Tourism Council: London, 2009.

[16] Meira Cartea, P.A., Comunicar el cambio climático. Escenario Social y Líneas de Acción. Organismo Autónomo Parques Nacionales, Ministerio de Medio Ambiente y Medio Rural y Marino: Madrid, 2009. 
[17] Becken, S., How Tourists and Tourism Experts Perceive Climate Change and Carbon offsetting Schemes. Journal of Sustainable Tourism, 12(4), pp. 332-345, 2004.

[18] Braun, L, Lohmann, M., Maksimovic, O., Meyer, M., Merkovic, A., Messerschmidt, E., Riedel, A. \& Turner, M., Potential impact of climate change effects on preferences for tourism destinations. A psychological pilot study. Climate Research, 11(3), pp. 247-254, 1999.

[19] Amelung, B. \& Viner, D., Mediterranean tourism: exploring the future with the tourism climatic index. Journal of Sustainable Tourism, 14(4), pp. 349-366, 2006.

[20] Amelung, B., Nicholls, S. \& Viner, D., Implications of global climate change for tourism flows and seasonality. Journal of Travel Research, 45(3), pp. 285-296, 2007.

[21] Bigano, A., Hamilton, J.M., Maddison, D.J. \& Tol, R.S.J., Predicting Tourism Flows under Climate Change. Climatic Change, 79(3-4), pp. 175-180, 2006.

[22] Hamilton, M., Maddison, D.J. \& Tol, R.S.J., The Effects of Climate Change on International Tourism. Climate Research, 29(3), pp. 245-254, 2005.

[23] Lise, W. \& Tol, R., Impact of Climate on Tourist Demand. Climatic Change, 55(4), pp. 429-449, 2002.

[24] Maddison, D., In search of warmer climates?. The impact of climate change on flows of British tourists. Climatic Change, 49(1-2), pp. 193-208, 2001.

[25] Scott, D., McBoyle, G. \& Schwartzentruber, M., Climate change and the distribution of climatic resources for tourism in North America. Climate Research, 27(2), pp. 105-117, 2004.

[26] Gössling' S., Bredberg, M., Randow, A., Sandström, E. \& Svensson, P., Tourist Perceptions of Climate Change: A Study of International Tourists in Zanzibar. Current Issues in Tourism, 9(4-5), pp. 419-435, 2006.

[27] Becken, S., Tourists' Perception of International Air Travel's Impact on the Global Climate and Potential Climate Change Policies. Journal of Sustainable Tourism, 15(4), pp. 351-368, 2007.

[28] Dawson, J., Stewart, E.J., Lemelin, H. \& Scott, D., The carbon cost of polar bear viewing tourism in Churchill, Canada. Journal of Sustainable Tourism, 18(3), pp. 319-336, 2010.

[29] Cohen, S. \& Higham, J., Eyes wide shut? UK consumer perceptions on aviation climate impacts and travel decisions to New Zealand. Current Issues in Tourism, 14(4), pp. 323-335, 2011.

[30] McKercher, B., Prideaux, B., Cheung, C. \& Law R., Achieving voluntary reductions in the carbon footprint of tourism and climate change. Journal of Sustainable Tourism, 18(3), pp. 297-317, 2010.

[31] Becken, S., How Tourists and Tourism Experts Perceive Climate Change and Carbon offsetting Schemes. Journal of Sustainable Tourism, 12(4), pp. 332-345, 2004. 
[32] Marshall, N.A., Marshall, P.A., Abdulla, A., Rouphael, T. \& Ali, A., Preparing for climate change: recognising its early impacts through the perceptions of dive tourists and dive operators in the Egyptian Red Sea. Current Issues in Tourism, 14(6), pp. 507-518, 2011.

[33] Scott, D., Gössling, S. \& De Freitas, C.R., Preferred climates for tourism: cases studies from Canada, New Zealand and Sweden. Climate Research, 38(1), pp. 61-73, 2008.

[34] Beckmann, S.C., In the eye of the beholder: Danish consumer-citizens and sustainability. Consumers, policy and the environment: a tribute to Folke Olander (ed) K.G. Grunert, \& J. Thogersen, Berlin: Springer, pp. 265-299, 2005.

[35] Meira, P.A., Arto, M. \& Montero, P., La sociedad ante el cambio climático. Fundación MAPFRE: Madrid, 2009.

[36] Milfont, T.L., The effects of social desirability on self-reported environmental attitudes and ecological behaviour. Environmentalist, 29, pp. 263-269, 2008.

[37] Meira, P.A., Arto, M. \& Montero, P., La sociedad ante el cambio climático. Fundación MAPFRE: Madrid, 2009.

[38] IPCC, Climate Change 2013: The Physical Science Basis. Contribution of Working Group I to the Fifth Assessment Report of the Intergovernmental Panel on Climate Change. Cambridge University Press: Cambridge, 2013.

[39] Stern, N., The Economics of Climate Change: The Stern Review. Cambridge University Press: Cambridge, 2006.

[40] UNWTO, Climate Change and Tourism. Proceedings of the 1 st International Conference on Climate Change and Tourism (Djerba, Tunisia, 2003). UNWTO: Madrid, 2003.

[41] UNWTO, From Davos to Bali: A Tourism Contribution to the Challenge of Climate Change. UNWTO: Madrid, 2007.

[42] UNWTO, From Davos to Copenhaguen and Beyond: Advancing Tourism's Response to Climate Change. Background paper, UNWTO, UNWTO: Madrid, 2009. 